\title{
Oxovanadium(IV) Complexes Containing VO(ONS) Basic Core: Synthesis, Structure, and Spectroscopic Properties
}

\author{
Yoon Jung Jang, Uk Lee," and Bon Kweon Koo* \\ Deparment of Chemisty, Caholic University of Daegu, Gyeongsan 7/2-702, Korea. "E-mail: bkkooialcuacekr \\ ${ }^{\dagger}$ Department of Chemistri. Pukvong National University. Pusan 608-737, Korea \\ Recened Aligust 7. 2004
}

\begin{abstract}
Some mononuclear oxovanadium(IV) complexes having the general formula [VOL(bidentate)] (1-4) of which $\mathrm{L}$ is tridentate ONS-donor salicylaldehyde S-methyldithiocarbazate (sal-moltc ${ }^{2}$ ) or salicylaldehyde 4phenylthiosemicarbazate (sal-phtsc ${ }^{2}$ ) and bidentate stands for 2,2'-bipyridyl (bpy) or 1,10-phenanthroline (phen) have been synthesized. The complexes were characterized by elemental analyses, FAB mass, UV, IR spectroscopy, and cyclic voltammetry. Two of the complexes [VO(sal-mdtc)(bpy)] (1) and [VO(sal-mdtc) (phen)] (2) were crystallographically characterized. The structures revealed that vanadium atom is octahedrally coordinated by the $\mathrm{O}, \mathrm{N}$, and $\mathrm{S}$ donor atoms of the tridentate ligand, the two $\mathrm{N}$ atoms of bidentate ligand, and the oxo atom. The oxygen donor, occupying an apical position has a trans-labilizing effect, resulting in elongation of the $\mathrm{V}-\mathrm{N}$ bond. The cyclic voltammograms of the complexes exhibited one cathodic response in the range $-1.45 \cdots-1.52 \mathrm{~V}$ due to the reduction of $\mathrm{V}(\mathrm{V})$ to $\mathrm{V}(\mathrm{III})$.
\end{abstract}

Key Words : Oxovanadium(IV) complexes, O,N,S-Donor ligands, Crystal structure

\section{Introduction}

Vanadium chemistry has received the intense attention because of its relevance to several biological and industrial ${ }^{2}$ processes. Vanadium is a bioessential element ${ }^{3}$ that produce significant physiological effects. Probably the most important physiological effect is the insulin-like properties of both vanadate and oxovanadium(IV) species. although this has not yet been clearly proved for humans." However, it is known that the vanadium compound has a great variety of physiological effects in different oxidation states and forms. The mechanism of the insulin-like effects of vanadium compounds is not yet fully understood. ${ }^{\circ}$ Clarification of the interactions of VO(IV) with proteins may promote understanding of some of the biological effects of vanadium. $V O(J V)$ can potentially interact with amine. amide, hydroxyl, imidazole, thiolate, and carboxylate functionalities of proteins."

In order to understand the function of VO(IV) species in diabetes and in various biological process in general, it is first necessary to develop its coordination chemistry with biologically relevant ligands such as peptides and in particular sulfhydryl-containing peptides. ${ }^{6 b}$ To date, numerous complexes of oxovanadium(IV) have been prepared and structurally characterized, but in most of these investigations nitrogen and/or oxygen donor ligands are used to bind the metal center in the oxidation states from +3 to +5 at limited nuclarity range. ${ }^{\overline{ }}$ In this paper, we report the synthesis and structural and physicochemical characterization of oxovanadium (IV) complexes of two tridentate Schiff base ligands, viz. salicylaldehyde S-Inethyldithiocarbazone (sal-mdtc $\mathrm{H}_{2}$ ) and salicylaldehyde 4-phenylthiosemicarbazone (sal-phts $\mathrm{H}_{2}$ ), which are of intrinsic interest because of the formation of a basic VO(ONS) core having one or more vacant coordination site(s) to potentially bind an ancillary ligand. Alternatively, the available site could be involved in bridging to a second vanadium center, forming a dinuclear complex. ${ }^{76.8}$<smiles>CS/C(S)=N/N=C/c1ccccc1O</smiles>

Experimental Section

Materials and measurements. VO(acac), salicylaldehyde. 4-phenyl-3-thiosemicarbazide, 2,2'-bipyridyl (bpy), and 1,10-phenanthroline monohydrate (phen) were purchased from Aldrich Chemical Co. S-methyldithiocarbazone" and the ligands, sal-mdtc $\mathrm{H}_{2}$ and sal-phts $\mathrm{CH}_{2}$ were prepared as described in the literature. ${ }^{10}$ All other chemicals and solvents were obtained from commercial sources and used as received.

Carbon, hydrogen, nitrogen, and sulfur analyses were carried out using a Carlo Erba Model EA-I106 CHNS/O Analyzer. Positive-jon $\mathrm{FAB}$ mass spectra were obtained using a JEOL JMS 700 high resolution mass spectrometer in a m-nitrobenzyl alcohol matrix. Melting point determinations were carried out with a Laboratory Devices Inc. Mellemp II. Molar conductivities were determined in DMSO at $25^{\circ} \mathrm{C}$ with a YSI Model 31 conductivity bridge. The IR spectra were recorded as $\mathrm{KBr}$ disk using a Mattson Polaris FI-JR spectrophotometer in the range $500-4,000 \mathrm{~cm}^{-1}$. UV! Vis spectra were obtained in DMSO, using a Milton Roy Spectronic Genesys 2 spectrophotometer. Electrochemical measurements were performed using a EG\&G Model 263 electrochemical system. A three-electrode cell comprising a 
platinum electrode, a platinum-wire counter electrode. and a $\mathrm{Ag} / \mathrm{Ag}^{-}$was used. The concentrations of oxovanadium complexes were $1 \times 10^{-3} \mathrm{M}$ with $0.1 \mathrm{M}$ tetraethylanmonium percllorate (TEAP) as the supporting electroly te in DMSO $(10 \mathrm{~mL})$

\section{Preparations.}

[VO(sal-mdtc)(bpy)] (1): To a well-stirred green suspension of $\mathrm{VO}(\mathrm{acac})=(1.36 \mathrm{mmol} .0 .361 \mathrm{~g})$ in methanol (15 $\mathrm{mL})$ was added an equimolar amount of bpy $(0.212 \mathrm{~g})$ and sal-mdtcH: $(0.308 \mathrm{~g})$. respectively. The resulting brown suspension was stirred for $6 \mathrm{~h}$ at room temperature. during which a purple solid appeared. After the product was allowed to stand at room temperature overnight, the solid was collected by filteration, washed with $\mathrm{Et}-\mathrm{O}$, and dried in vacto. Yield: $0.495 \mathrm{~g}(81 \%)$ mp $230^{\circ} \mathrm{C}$ (dec.). Anal. Calcd. for $\mathbf{C}_{19} \mathbf{H}_{16} \mathbf{N}_{4} \mathbf{O}_{2} \mathrm{~S}_{2} \mathbf{V}$ : C. $51.00: \mathrm{H}, 3.60 ; \mathrm{N}, 12.52 ; \mathrm{S}, 14.33$. Found: C. 50.73: H, 3.56; N, 12.01: S. 14.75. FAB-MS. m/z: $[\mathrm{MH}]^{+} .448$; [VO $\left.(\mathrm{bpy})\right]^{+}$. 239: [VO(bpy)] ${ }^{+} .223 . \Lambda_{\mathrm{XI}}$ (Mho $\mathrm{cml}^{2} \mathrm{~mol}^{-1}$ ): 3.2 . UV/vis. (nm. $\log \varepsilon$ ): 730 (l.64). 538 (2.14). 394 (3.98). $286(4.42)$. Significant infrared bands $\left(\mathrm{cm}^{-1}\right)$ : $954\left(v_{V=0}\right), 1601\left(v_{\mathrm{C}=\mathrm{N}}\right)$.

[VO(sal-mdtc)(phen)] (2): This compound was obtained following the same procedure as described for 1 . using phen instead of bpy. Yield: $0.420 \mathrm{~g}(65 \%)$. mp $258^{\circ} \mathrm{C}$ (dec.). Anal. Calcd. for $\mathrm{C}_{21} \mathrm{H}_{16} \mathrm{~N}_{4} \mathrm{O}_{2} \mathrm{~S}_{2} \mathrm{~V}$ : C, 53.50: H. 3.42; N. 11.88; S, 13.60. Found: C, 53.70: H. 3.44: N, 11.55: S.
13.90. FAB-MS. n/z: $[\mathrm{MH}]^{-}, 472$ : $\left[\mathrm{VO}_{2} \text { (phen) }\right]^{+}$. 263;

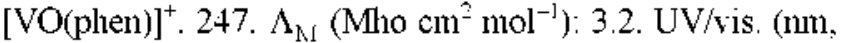
$\log \varepsilon$ ): 738 (1.69), $520(2.16) .400$ (3.90), 268 (4.54). Significant infrared bands $\left(\mathrm{cm}^{-1}\right): 956\left(v_{v=0}\right) .1601\left(v_{\mathrm{C}=\mathrm{N}}\right)$.

Remaining oxovanadium(IV) complexes 3 and 4 were prepared in a fashion similar to that adopted for 1 . but using sal-phtscH $\mathrm{H}_{2}$ as the tridentate Schiff base ligand.

[VO(sal-phtsc)(bpy)] (3): Yield: $0.400 \mathrm{~g}(60 \%) . \mathrm{mp} 260$ ${ }^{\circ} \mathrm{C}$ (dec.). Anal. Calcd. for $\mathrm{C}_{24} \mathrm{H}_{19} \mathbf{N}_{3} \mathrm{O}_{2} \mathrm{SV}$ : C. 58.54: $\mathrm{H}$, 3.89: N, 14.22; S. 6.51. Found: C. 58.45: H. 3.82: N. 14.34: S. 6.67. FAB-MS, m/z: $[\mathrm{MH}]^{-}, 493:[\mathrm{VO}(\mathrm{bpy})]^{-}, 239$ : [VO(bpy)] $]^{+}$. 223. $\Lambda_{\mathrm{M}}\left(\mathrm{Mho} \mathrm{cm}^{2} \mathrm{~mol}^{-1}\right): 2.1$. UV/ris. (nm, $\log \varepsilon): 730$ (1.60). 532 (2.13), 400 (4.20). 274 (4.45). Significant infrared bands $\left(\mathrm{cm}^{-1}\right): 956\left(v_{V=0}\right) .1599\left(v_{\mathrm{C}=\mathrm{N}}\right)$.

[VO(sal-phtsc)(phen)] (4): Yield: $0.300 \mathrm{~g}(45 \%)$. mp 280 ${ }^{\circ} \mathrm{C}$ (dec.). Anal. Calcd. for $\mathrm{C}_{26} \mathrm{H}_{19} \mathrm{~N}_{3} \mathrm{O}_{2} \mathrm{SV}$ : C. 60.46: $\mathrm{H}$, 3.71: N, 13.56; S. 6.21. Found: C. 60.93: H. 3.73: N. 13.15: S. 6.43. FAB-MS. $\mathrm{m} / \mathrm{z}:[\mathrm{M}]^{-}$, 516; [VO (phen)] $]^{-}, 263$; [VO(phen)] ${ }^{+}$. 247. $\Lambda_{\mathrm{M}}$ (Mho $\mathrm{cm}^{2} \mathrm{~mol}^{-1}$ ): 2.1. UV/ris. (nm, $\log \varepsilon): 747$ (1.78). 520 (2.30), 406 (4.13). 268 (4.65). Significant infrared bands $\left(\mathrm{cm}^{-1}\right): 944\left(v_{V=0}\right) .1601\left(v_{\mathrm{C}=\mathrm{N}}\right)$.

Crystal structure determination of 1 and 2. X-ray quality crystals of both complexes. 1 and 2 were obtained by slow diffusion of ethyl alcohol into a saturated dichloromethane solution ( $1: 1$ ) of the brown powder, respectively. Data were collected on a STOE STADI $4^{11}$ four-circle

Table 1. Crystal data and structure refinement for complexes 1 and 2

\begin{tabular}{|c|c|c|}
\hline & Complex 1 & Complex 2 \\
\hline Empirical formula & $\mathrm{C}_{10} \mathrm{H}_{16} \mathrm{~N}_{4} \mathrm{O}_{2} \mathrm{~S}_{2} \mathrm{~V}$ & $\mathrm{C}_{21} \mathrm{H}_{10} \mathrm{~N}_{4} \mathrm{O}_{2} \mathrm{~S}_{2} \mathrm{~V}$ \\
\hline $\mathrm{Fw}$ & 447.42 & 471.44 \\
\hline Temp $(\mathrm{K})$ & $298(2)$ & $298(2)$ \\
\hline$\lambda(\dot{A})$ & 0.71069 & 0.71069 \\
\hline Crystal system & Monoclinic & Triclinic \\
\hline Space group & $\mathrm{P} 21 / \mathrm{n}$ & P-1 \\
\hline $\mathrm{a}(\AA)$ & $12.881(2)$ & $9.680(9)$ \\
\hline$b(A)$ & $9.312(1)$ & $9.970(5)$ \\
\hline$c(A)$ & $16.798(8)$ & $22.25(2)$ \\
\hline$\alpha\left(0^{\circ}\right)$ & 90 & $81.07(6)$ \\
\hline$\beta(0)$ & $101.38(2)$ & $85.73(8)$ \\
\hline$y\left(0^{\circ}\right)$ & 90 & $78.23(6)$ \\
\hline$V\left(A^{3}\right)$ & $1975(1)$ & $2074(3)$ \\
\hline Z & 4 & 4 \\
\hline $\mathrm{D}_{\text {cali: }}\left(\mathrm{Mg} / \mathrm{m}^{3}\right)$ & 1.505 & 1.510 \\
\hline$\mu\left(\mathrm{mm}^{-1}\right)$ & 0.736 & 0.706 \\
\hline$F(000)$ & 916 & 964 \\
\hline Crystal size (mm) & $0.63 \times 0.25 \times 0.19$ & $0.38 \times 0.25 \times 0.19$ \\
\hline Theta range & $1.83-27.47^{\circ}$ & $1.86-27.51^{\circ}$ \\
\hline Index ranges & $h=-16 \rightarrow 16, k=08 \rightarrow 12, l=0 \rightarrow 21$ & $h=-12 \rightarrow 12, k=-12 \rightarrow 12, l=0 \rightarrow 28$ \\
\hline Reflections/lunique & $4526 / 4526[$ Rint $=0.0000]$ & $9527 / 9527[\mathrm{Rint}=0.00000]$ \\
\hline Completeness to theta & $99.9 \%$ & $99.9 \%$ \\
\hline Data/restraints/parameters & $4526 / 0 / 253$ & $9527 / 0 / 541$ \\
\hline$R[I>2(I)]$ & $R_{1}=0.0494, w R_{2}=0.0473$ with 3310 reflections. & $R_{1}=0.0727, w R_{1}=0.0636$ with 6082 reflections. \\
\hline$R$ (all data) & $R_{1}=0.0826, w R_{2}=0.0512$ & $R_{1}=0.1357, w R_{2}=0.703$ \\
\hline G.O.F. on $\mathrm{F}^{2}$ & 1.839 & 1.984 \\
\hline Largest diff. peak and hole & 0.330 and $-0.316 \mathrm{eA}^{-3}$ & 0.938 and $-0.851 \mathrm{eA}^{-3}$ \\
\hline
\end{tabular}


Table 2. Selected bond lengths $(X)$ and angles (") for complexes 1 and 2

\begin{tabular}{crr}
\hline Bond lengths & Complex 1 & Complex 2 \\
\hline V-O1 & $1.593(3)$ & $1.598(2)$ \\
V-O2 & $1.961(2)$ & $1.971(2)$ \\
V-S1 & $2.407(1)$ & $2.431(2)$ \\
V-N1 & $2.082(2)$ & $2.070(3)$ \\
V-N3 & $2.139(2)$ & $2.135(3)$ \\
V-N4 & $2.318(2)$ & $2.353(3)$ \\
V1-N2 & $1.424(2)$ & $1.410(4)$ \\
C.7-NI & $1.292(3)$ & $1.301(4)$ \\
C8-N2 & $1.288(3)$ & $1.308(4)$ \\
O1-V-O2 & $100.58(9)$ & $101.2(1)$ \\
O1-V-N1 & $102.83(8)$ & $104.5(1)$ \\
O1-V-S1 & $99.33(8)$ & $96.4(1)$ \\
O1-V-N3 & $96.12(8)$ & $95.8(1)$ \\
V1-V-N4 & $88.68(7)$ & $86.6(1)$ \\
V3-V-N4 & $72.31(7)$ & $73.0(1)$ \\
O2-V-NI & $88.52(7)$ & $87.9(1)$ \\
O2-V-N3 & $92.70(7)$ & $89.1(1)$ \\
O2-V-N4 & $80.72(7)$ & $81.7(1)$ \\
S1-V-N1 & $80.62(6)$ & $80.8(1)$ \\
S1-V-N3 & $91.74(6)$ & $96.3(1)$ \\
S1-V-N4 & $81.12(6)$ & $82.5(1)$ \\
O1-V-N4 & $168.42(8)$ & $168.5(1)$ \\
V1-V-N3 & $160.46(7)$ & $159.6(1)$ \\
O2-V-S1 & $159.01(6)$ & $161.02(8)$ \\
\hline & & \\
& & \\
\hline
\end{tabular}

diffractometer using graphite monochromatized Mo-K $\alpha$ radiation by $\omega-2 \theta$ scan. Unit cell parameters were determined by least-squares fit of 32 (1) and 28 (2) reflections having $\theta$ values in the ranges of 9.5-10.4 (1) and 9.1-10.7 (2), respectively. Intensities of three check reflections were measured after every $\mathrm{l} h$ during the data collection to monitor the crystal stability for both complexes and there was no significant change in the intensities of the check reflections. The structures were solved by direct method ${ }^{12}$ and refined on $F^{2}$ by full-matrix least-squares procedures. ${ }^{1.3}$ All non-hydrogen atoms were refined using anisotropic thermal parameters. Hydrogen atoms were included in the structure factor calculation at idealized positions by using riding model, but not refined. The data collection and structure solution parameters are listed in lable I, together with standard discrepancy indices, $R$ and $w R$.

\section{Results and Discussion}

The reactions of vanadyl acetylacetonate with the Schiff base ligands derived from salicylaldehyde and S-methyldithiocarbazate or 4-phenylthiosemicarbazide, and 2,2'bipyridine or 1.10-phenanthroline in methanol solution gave monomeric oxovanadium(IV) complexes, 1-4 of VOL (bidentate) type ( $\mathrm{L}=\mathrm{sal}-\mathrm{mdtc}^{2-}$ and $\mathrm{sal}^{2} \mathrm{phtsc}^{2-}$ ), respectively. The formulations were in accordance with the data of elemental analysis and physicochemical measurements.

Positive-ion $\mathrm{FAB}$ mass spectra of the complexes contain a

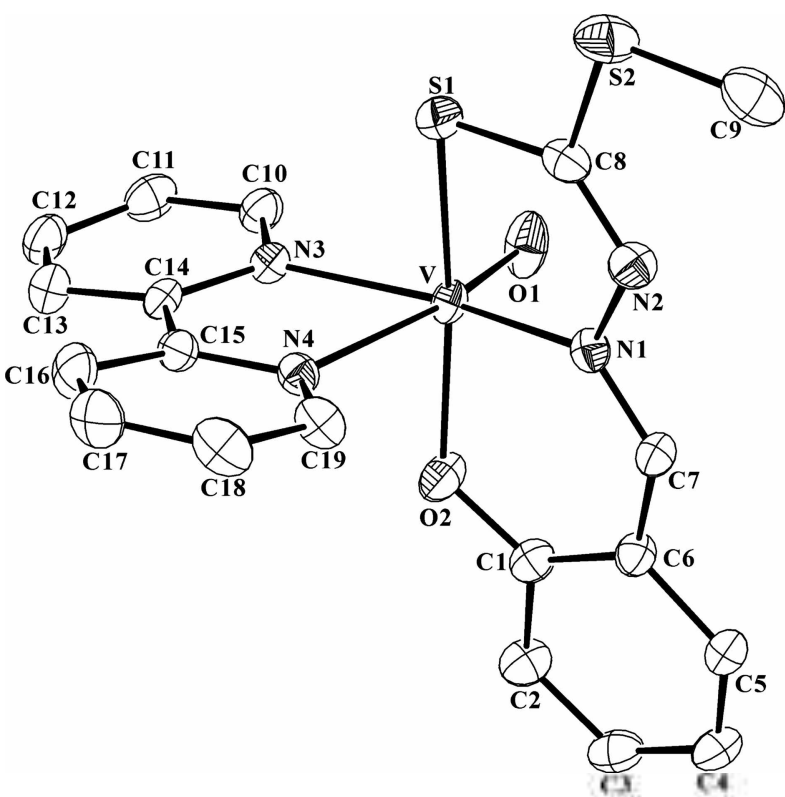

Figure 1. Ortepll/1 drawing of 1. Displacement ellipsoids are drawn at $30 \%$ probahility level and $H$ atoms have been omitted for clarity.

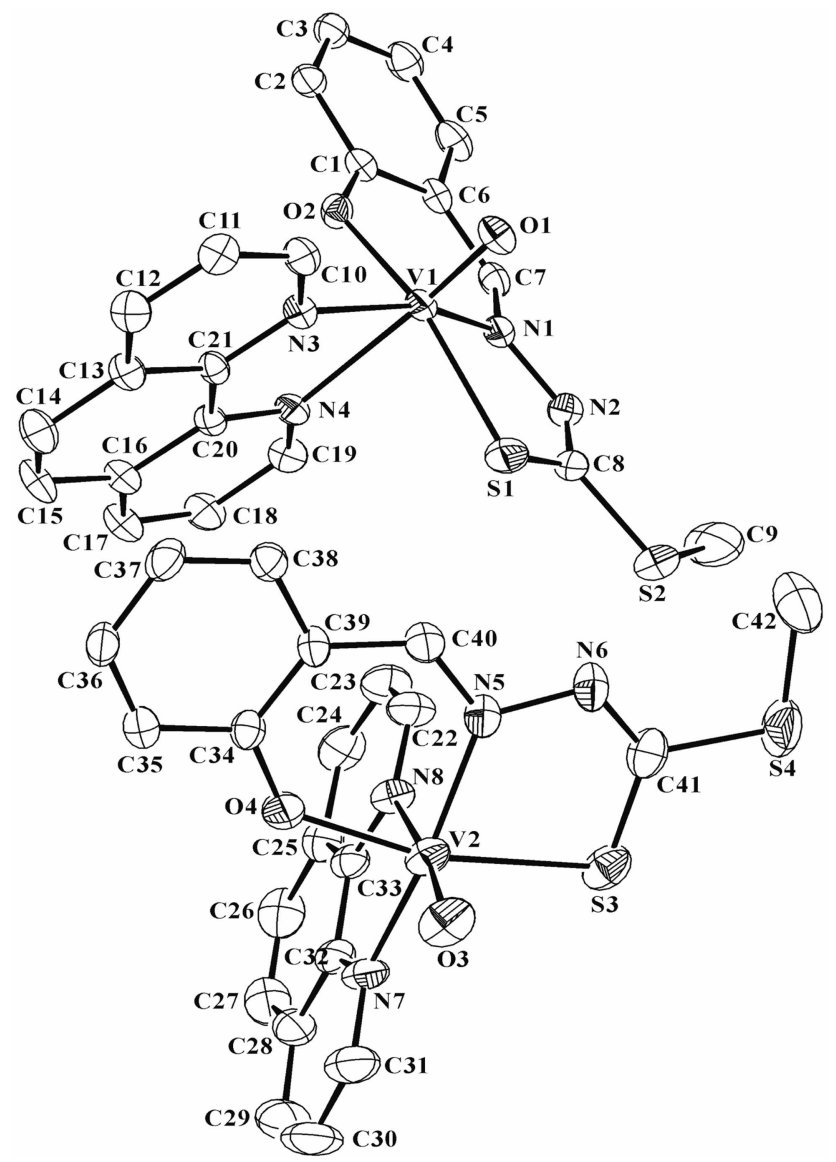

Figure 2. Orkepll] ${ }^{14}$ drawing of 2. Displacement ellipsoids are drawn at $30 \%$ probability level and $\mathrm{H}$ atoms have been omitted for clarity.

molecular ion peak $\left(\mathrm{MH}^{+}\right)$together with fragmentation peaks corresponding to the positive ions [ $\mathrm{VO}_{2}$ (bidentate $\left.)\right]^{-}$ 
and $[\mathrm{VO}$ (bidentate $)]^{-}$. respectively. The spectrum for a representative complex 1 showed peaks due to the $[\mathrm{MH}]^{+}$. $\left[\mathrm{VO}_{2}(\mathrm{bpy})\right]^{+}$, and [VO(bpy)] ${ }^{-}$at $\mathrm{m} / \mathrm{z} 448,239$. and 223. respectively.

Description of crystal structures. Compounds 1 and 2 display essentially similar coordination geometry. Ortep representations of two complexes are shown in Figure 1 and 2. respectively. Selected interatonic parameters for the complexes are listed in Table 2. In each cases, the unit cell consists of ranadyl moiety, one trifunctional. and one bidentate ligand that occupies the fifth and sixth metal coordination sites. Unlike complex 1. complex 2 contains two crystallographically discrete molecular entities having nearly similar geometric parameters, with the closest non- $\mathrm{H}$ intermolecular contact of $3.691(6) \hat{A}$ occuring between the $\mathrm{C} 12$ and $\mathrm{C} 37$ atoms in the unit cell.

The $\mathrm{V}=\mathrm{O}$ bond (1.593(2) for 1 and 1.598(3) $\AA$ for 2) was unexceptional, falling within the range 1.588-1.635 $\mathrm{A}^{15}$ The vanadium atom was displaced out of the best least squares plane (mean deviation; $0.009 \AA$ for 1 and $0.025 \AA$ for 2 ) formed by the three donor atoms of sal-mdtc ${ }^{2-}$ and the equatorial donor atom of the bidentate ligand toward the vanadyl oxygen by $0.356 \AA(0.347 \AA$ for 2$)$. The sal-mdtc ${ }^{2-}$ is a tridentate meridional ligand that provides thiolate sulfur $(\mathrm{V}-\mathrm{SI}=2.407(\mathrm{l}) \AA(1)$ and $2.43 \mathrm{l}(2) \AA(2))$, imine nitrogen $(\mathrm{V}-\mathrm{Nl}=2.082(2) \AA(1)$ and $2.070(3) \AA(2))$, and phenolate oxygen $(\mathrm{V}-\mathrm{O} 2=1.961(2) \AA(1)$ and $1.971(2) \AA(2))$ donor atomis to the vanadium(IV). This V-S distance is much longer than that observed in [VOL $(\mathrm{OMe})](\mathrm{L}=\mathrm{S}$-methyl 3 . ((2-hydroxyphenyl)methyl)dithiocarbazate) (V-S 2.318 A). ${ }^{16}$ The distances of vanadium-imine nitrogen and vanadiumphenolate oxygen are similar to the corresponding distances observed in [VO(SALMH)(acac)] (SALMH $=4$ - (2-(salicylideneanino)ethyl) imidazole). ${ }^{17}$ The bidentate ligand that occupies the fifth and sixth vanadium coordination sites shows a small disparity in the V-N distances between V-N3 (2.139(2) $\AA$ (1) and 2.135(3) $\AA$ (2)) and V-N4 (2.318(2) $\AA$ (1) and 2.353(3) $\mathrm{A}(2)$ ), which can be related to greater trans influence of the oxo group on the V-N4 bond. The relatively short C7-N1 of 1.292(3) A and C8-N2 bond distances of $1.288(3) \AA(1.301(4)$ and 1.308 (4) $A$ for 2) (normal single bond is $1.364 \mathrm{~A}^{17}$ ). coupled with the NI-N2 distance of 1.424 (2) $\AA$ (1.410(4) $\AA$ for 2), indicate that there is conjugation along the backbone of the tridentate ligand. The metric parameters for other five- and six-membered rings are unexceptional and compared closely to those in related molecules. ${ }^{18}$ Both of the five- and six-membered rings which are formed upon coordination of ligand are almost planar: for the complex of 1 . the mean deviations of the planes V-S1-C8-N2-N1 and V-O2-C1-C6 -C7-N1 from the least-square plane are 0.030 and $0.116 \AA(0.018$ and 0.107 $A$ for 2). respectively and each of the dihedral angles of the V-S1-C8-N2. V-O2-C1-C6. and V-N1-C7-C6 to the plane. V-Sl-C8-N2-N1 is $1.29(0.12)$. 17.69(0.12), and $2.31(0.14)^{\circ}$ $\left(0.60(0.11), 16.22(0.18)\right.$, and $1.27(0.16)^{\circ}$ for 2 , respectively). The dihedral angle between two aromatic planes. $\mathrm{N} 3-\mathrm{Cl} 10-\mathrm{Cl1}-\mathrm{Cl} 2-\mathrm{Cl} 3-\mathrm{Cl} 4$ (mean deviation $0.017 \AA$ ) and
Table 3. Electrochemical data $a^{a}$ for the oxovanadium(IV) complexes in DMSO

\begin{tabular}{|c|c|c|}
\hline & \multirow{2}{*}{ complex } & $\mathrm{V}(\mathrm{IV}) / \mathrm{V}(\mathrm{III})$ \\
\hline & & $\mathrm{E}_{p c}{ }^{b}, \mathrm{~V}$ \\
\hline 1 & $\mathrm{VO}(\mathrm{sal}-\mathrm{m} d \mathrm{dc})(\mathrm{bpy})$ & -1.45 \\
\hline 2 & $\mathrm{VO}$ (sal-mdtc)(phen) & $-1.45(-1.38)$ \\
\hline 3 & $\mathrm{VO}$ (sal-phtsc)(bpy) & $-1.52(-1.34)$ \\
\hline 4 & VO(sal-phtsc)(phen! & $-1.48(-1.43)$ \\
\hline
\end{tabular}

"Potentials referred to a Ag As electrode in DMSO with TEAP as supporting electrolvte: scan rate $100 \mathrm{mV}$ is at $25{ }^{\circ} \mathrm{C}$. Values in parentheses are coupled oxidation peaks observed with a complete $\mathrm{CV}$ cycle.

N4-C15-C16-C17-C18-C19 (mean deviation $0.008 \AA$ ) of the bipyridine ligand in the complex 1 is $13.26(0.13)^{\circ}$.

Structural determination of sal-phtsc ${ }^{2-}$ ligand complexes was not possible as the complexes, 3 and + eluded all attempts to grow diffraction quality crystals.

Spectral and electrochemical properties. The IR spectra of the complexes have several prominent bands appearing at ca. 953 and $1601 \mathrm{~cm}^{-1}$ due to $v_{v=0}$ and $v_{C=1}$ stretching modes. respectively. ${ }^{7 c, 15}$ The shift of the band at $c a .1601$ $\mathrm{cm}^{-1}$ to lower frequency compared to the azomethane group $\left(v_{C=1}\right.$ at $c a .1620 \mathrm{~cm}^{-1}$ ) of free ligand indicates that the azomethane nitrogen acts as donor atom to the vanadium atom. The electronic absorption spectra of the complexes exhibited two bands of low intensity $(\log \varepsilon=1.60-2.30)$ at ca. 736 and $528 \mathrm{~nm}$ due to the ligand-field transitions $\mathrm{d}_{\mathrm{yg}}$ $\rightarrow \mathrm{d}_{\mathrm{v}} / \mathrm{d}_{\mathrm{y}}$ and $\mathrm{d}_{\mathrm{y}} \rightarrow \mathrm{d}_{x^{2}-y^{2}}$. respectively, characteristic of oxovanadium(IV) cluromophore. ${ }^{15}$ A third $\mathrm{d}-\mathrm{d}$ band expected at higher energy due to $\mathrm{d}_{x y} \rightarrow \mathrm{d}_{2}$ - transition was probably obscured by the tail of the ligand-to-metal or intraligand charge-transfer absorption. A strong band in the 406-394 nm region ( $\log \varepsilon=3.90-4.20$ ) is due to the ligand-to-metal charge-transfer $\left(\mathrm{PhO}^{-} \rightarrow \mathrm{V}^{16}\right.$ and the remaining bands appearing in the UV region are due to intraligand transitions. These transitions are consistent with tetragonally symmetry commonly associated with spectra of the vanadyl complexes. ${ }^{7 a, 7 b}$ The redox behavior of complexes 1-4 was examined by cyclic voltammetry in DMSO and the results in the potential range 0.0 to $-2.0 \mathrm{~V}\left(\mathrm{vs} . \mathrm{Ag} / \mathrm{Ag}^{+}\right.$) are given in Table 3. All complexes displayed one cathodic response in the range $-1.45 \sim-1.52 \mathrm{~V}$. The reduction waves are found to be coupled to weak and broad anodic peaks in the range $-1.34 \sim-1.43 \mathrm{~V}$. On compairing the cyclic voltammograms of the authentic one-electron reductions observed in the cases of other monomeric oxovanadium(IV) complexes. $76.7 c, 16$ it appears that the reduction peak is due to the reduction of $\mathrm{V}$ (IV) to V(III). Since a blanck CV run of ligands did not have any redox peak in the range studied here. the redox process is metal based. The reduction potentials of complexes 1 and 2 are more positive compared with complexes 3 and 4 . indicating that complexes with salndtc ${ }^{2-}$ are more easily reduced than those of sal-phtsc ${ }^{2-}$ ligand complex due to the inductive effect of the substituent in dimethyl sulfoxide. lits $^{\text {tim }}$ 


\section{Conclusions}

Some new oxovanadium(IV) complexes with the ONSdonor ligands sal-nidtc ${ }^{\hat{2}}$ and sal-phtsc ${ }^{\hat{2}}$, and bpy or phen as bidentate ligand have been synthesized and characterized. Crystal structure analyses of complexes 1 and 2 revealed that in each of them. a phenolate oxygen. an inine nitrogen. and a deprotonated sulfur atom of the Schiff base, and a bidentate nitrogen atom are coordinated in the equatorial plane with vanadyl oxygen and the remaining bidentate nitrogen atom being in the axial position. The V-N4 distance is much longer than that of other $\mathrm{V}-\mathrm{N} 3$ bond of bidentate ligand due to the trans effect of $\mathrm{Ol}$ group. The cyclic voltanmograms of the complexes exhibited one cathodic response in the range $-1.45 \sim-1.52 \mathrm{~V}$ due to the reduction of V(IV) to V(III). and the reduction potentials of complex 1 and $\mathbf{2}$ are more positive compared with complex 3 and 4 . indicating that complexes with sal-mdtc ${ }^{\hat{i}}$ are more easily reduced than those of sal-phtsc ${ }^{2-}$ ligand conplex due to the inductive effect of the substituent in dimethyl sulfoxide.

Supporting information available. Crystallographic data for the structure reported here have been deposited with the Cambridge Crystallographic Data Center (Deposition No. CCDC-245558 (1) and 245557 (2)). The data can be obtained free of charge via www:cck.com.c. th conts retrieving html (or from the CCDC, 12 Union Road. Cambridge CB2 IEZ. UK: fax: +44-1223-336033; e-mail: depositaccdc.cam.ac.uk).

\section{References}

1. (a) Chasteen. N. D. Tanaditum in Biological Srstems: Kluwer Academic Publishers: Dordrecht. The Netherlands. 1990. (b) Rehder. D. Angew: Chem. Int. Ed. Engl. 1991. 30. 148. (c) Butler. A.: Walker. I. V. Chem. Rev. 1993.93. 1937.

2. (a) Rouxel. I.: Brec. R. Amm. Rev. Hater Sci. 1986. 16, 137. (b) Costisor. O.: Linert. W. Rev Inorg. Chem. 2002. 22. 125. (c) Reynolds. F.: Biggs. W. R.: Fetzer. J. C. Liq. Fitel Technol. 1985. 3. 423. (d) Nakajima. K.: Kojima. M:: Fujita. J. Bull. Chemt. Soc. Jpn. 1990, 63, 2620. (e) Nakajina. K.: Kojima, M.: Torilmi, K.:
Saito. K.: Fujita. T. Bull. Chent. Soc. Jpn. 1989. 62.760.

3. (a) Thomas. S. S-II.: Russell. L.: Vincent. L. P. Coord Chem. Rev: 2002. 228. 1. (b) Hiromu. S.: Yoshitane. K.: Yutaka. Y.: Kenji. K.: Hiroyuki. Y. Coord. Chem. Rev. 2002. 226. 187.

4. Tamas, J:- Peter B: Ana, I. T: Joao, C. P.; Tamas, K. horg. Chim Acta 2002.339. 119.

5. (a) Rehder. D.: Siegel. H.: Siegel. A. Metal Ions in Biological Stutems: Marcel Dekiker: New York. 1995. (b) Rehder. D. Coord. Chent. Rev: 1999. 182.297.

6. (a) Thompson. K. H; Orwig. C. Coord. Chem. Rev 2001, 219221. 1033. (b) Orwig, C: Thompson. K. H.: Battel. M.: MoNeil J. $\mathrm{H}$; Siegel. H.; Siegel, A. Metal Ions in Biological Systems; Marcel Dekier: New York. 1995: Vol. 31.

7. (a) Herlk. H.: Antonio. B.: Ernst. E. van F.: Bert. T. G. L.: Taap. B.: Anthony. L. S.: Gerard. K. Whorg. Chent 1999. 38. 4079. (b) Mohammad. M. T: Anastasios, D. K.: Ron. B. G.; Oren. P. A.: Mary. M. M: Debbie, C. C. Inorg. Chem. 1997. 36. 1657. (c) Ryuji. A.; Satsuki, M; Miho. H: Takeyoshi, Y; Masunobu, M. Inorg. Chin. Acta 2004. 357. 1177. (d) Pessoa. J. C.: Tomaz. I.: Henriques. R. T. Inorg. Chm. Acta 2003.356. 121. (e) Swapnalee. S.: Diganta. K.: Pankaji. H.: Ruli. B.: Nashreen. S. I. Polbhedron 2004. 23, 1097. (f) Ando. R.: Yagyu. T.; Maeda, M. horg. Chim Acta 2004. 357, 2237. (g) Mukhopadhyay, A.; Padmaja, G.; Pal. Satyanaravan; Pal, Sanudranil horg Chem Comm 2003, 6, 381.

8. Dutta. S. K.: Samanta. S.: Kumar. S. B.: Han. O. H.: Burckel. P.: Pithkerton. A. A.: Chaudhury: M. Inorg. Chent 1999. 38. 1982.

9. (a) Kim. D. W.: Lee. U.: Koo. B. K. Bull. Korean Chem. Soc. 2004. 25. 1. (b) Ali. M. A.: Livingstone. S. E.; Phillips, D. J Inorg. Chim Acta 1973. 7, 179.

10. (a) Koo. B. K.: Lee. U. Bull. Korean Chem. Soc. 2002, 23.613. (b) Das. M.: Livingston. S. E. Horg. Chm. Acta 1976. 19.5.

11. STOE STADI H. A-RED \& X-SH.APE. X-ray structure evaluation package: STOE-Cie GMbh: Hilpertstrase 10. D64295. Darmstadt. Germany, 1996.

12. Sheldrick, G. M. Acta Cryst 1990, $4+6,467$.

13. Sheldrick, G. M. SHELIS97-2 and SHEL1797-2, University of Gottingen: Gottingen. Germany. 1997.

14. Farrugia. L. J. J. Appt Cnut 1997. 30.565.

15. (a) Koo. B. K.: Tang. Y. T.: Lee. U. Bull. Korean Chem. Soc. 2003. 24. 1014

16. Dutta, S. K.: Kumar. S. B.: Bhattacharya. S.: Tiekink, E. R. T; Chaudhun, M. Horg. Chem 1997.36, 4954.

17. Comman. C. R.: Kampf. J.: Lah. M. S.: Pecoraro. V. L. Inorg. Chent 1992.31.2035.

18. Bostos. C.: Burchhardt. O: Schrebler. R.: Carrillo. D: Arif. A. M.; Cowley, A. H.; Nunn. C. M. Horg. Chem. 1990. 29, 3996. 